\title{
Editorial: Technology, Policy, and the Right to Education
}

\author{
Barbara Spronk \\ Visiting Graduate Professor at Athabasca University - Canada’s Open University Sessional \\ Lecturer at the University of Guelph
}

On December 10, 1948 the General Assembly of the United Nations adopted and proclaimed the Universal Declaration of Human Rights. Article 26 of that declaration deals with the right to education. Its three clauses are:

(1) Everyone has the right to education. Education shall be free, at least in the elementary and fundamental stages. Elementary education shall be compulsory. Technical and professional education shall be made generally available and higher education shall be equally accessible to all on the basis of merit.

(2) Education shall be directed to the full development of the human personality and to the strengthening of respect for human rights and fundamental freedoms. It shall promote understanding, tolerance and friendship among all nations, racial or religious groups, and shall further the activities of the United Nations for the maintenance of peace.

(3) Parents have a prior right to choose the kind of education that shall be given to their children.

Almost 60 years have passed since this declaration. In that time, distance education has emerged as a way of extending educational opportunities to those for whom poverty, remote location, gender, disability, or dislocation has made education more of a luxury than a right, especially in the world's poverty zones. At basic and secondary levels, open schools and classrooms are using distance education approaches to help universalize primary education and make secondary education at least a possibility for those who would otherwise become permanent school leavers (cf. Yates \& Bradley, 2000, and Bradley, 2003). Perraton estimated that as many as 20 per cent of university students in developing countries were studying at a distance, compared with 12 per cent in industrialized countries (2000). Those percentages, no doubt, are considerably higher today. Nonetheless, 72 million children remain out of school, one in five adults is without basic literacy skills, and many pupils leave school without acquiring essential skills and knowledge (UNESCO, 2008). Is distance education helping to make a significant dent in these numbers?

In company with distance education journals worldwide, this special issue of the International Review of Research in Open and Distance Learning (www.irrodl.org) invited contributions that 
Barbara Spronk Editorial

Technology, Policy, and the Right to Education

Volume 9, Number 1, February 2008

addressed this question. Contributors were asked to focus on the following issues: What is the role of distance education in the implementation of the right to education? How is distance education involved when education is seen as a right? What is its position in educational policy, as a factor of quality and an instrument for liberty? Do the technologies of distance education act as enablers or barriers to achieving the universal right to education? In response, we received a number of papers that focus particularly on technology and policy.

First up is a trio of papers that concern the way in which technology is facilitating the production and dissemination of Open Educational Resources. Production costs of distance learning materials remain high, but thanks to digitization and communication technologies, the costs of reproduction and dissemination are almost non-existent. As a consequence, producer organizations, primarily universities, can make and are making their materials available to any individual or organization anywhere in the world for immediate use. Recipients are encouraged to adapt materials to meet their own needs. Producer institutions have formed consortia to share the costs of storing, cataloguing and disseminating their courseware, and to facilitate an expanded process of peer review. OpenCourseWare is one such endeavour, begun at the Massachusetts Institute of Technology in 2001.

Among the providers are Utah State University (Caswell, Henson, Jenson and Wiley) and the University of Southern Queensland (Huijser, Bedford and Bull). Caswell and colleagues present the positive case for this technology, arguing that by providing worldwide access to digital 'courseware,' distance education becomes not just a classroom alternative but a 'social transformer.' Huijser and colleagues are somewhat more circumspect, tempering this enthusiasm by detailing some of the challenges involved, in particular the continuing 'digital divide' and the risk of 'cyber imperialism.' OpenCourseWare are produced, after all, in cultural, political, and social contexts specific to their countries of origin, which at the moment are almost exclusively in the global North. Further, 'courseware' are not the same as 'courses'. The latter contain such learner support mechanisms as feedback on assessment, structured time-tabling, and person-toperson support, which distance educators continue to see as critical to the learning process (cf. Tait \& Mills, 2003 and the April 2003 issue of www.irrodl.org). Completion of 'courses' also leads to the conferring of a qualification, something that universities essentially sell. In terms of selling, Huijser and colleagues also point to the benefits to producer institutions of becoming known as purveyors of quality OpenCourseWare: students who have sampled these wares and liked what they see are more likely to sign up for the full package. Huijser et al. suggest that this may, in fact, be the real rationale for universities' involvement in the movement. Nonetheless, claim the authors, opening of access to quality materials is a byproduct of such potential value that the movement merits support and continuing work to overcome the challenges it poses.

Wilson adds a third dimension to this consideration of open educational resources by describing a new venture of The Open University of the United Kingdom called 'OpenLearn'. Wilson, picking up a point made by Huijser et al., notes that these materials, having been produced specifically for learners at a distance rather than for conventional classroom use, contain learning support mechanisms such as self-assessment quizzes and guidance for study. Wilson also adds a further international flavour to the discussion by comparing the views regarding possible take up of these materials by a university in South Africa and a college in the United Kingdom, in the process highlighting the differences in access to the Internet that characterize the two institutions but also their similarities of viewpoint regarding the appeal of the content on offer (high) and the role the acquired courseware would play in their curriculum (supplementary rather than core). 
Barbara Spronk Editorial

Technology, Policy, and the Right to Education

Volume 9, Number 1, February 2008

The next two papers continue the technology theme, by providing a comprehensive catalogue of the challenges that developing nations face in attempting to benefit from these e-learning developments (Gulati), and an account of a project in western China that is using technology for the professional development of rural teachers (Robinson). Gulati offers us a rather bleak prospect, arguing that although "the availability of new technologies may have opened up developing economies to the world market ... they have done little to help deprived groups gain access to educational opportunities" (p. 12). The barriers are familiar to anyone who has worked in countries of the global South - lack of educational and technological infrastructures, lack of trained teachers, negative attitudes toward distance learning, social and cultural restrictions imposed on girls and women, and inappropriate policy and funding decisions. Robinson's paper is more hopeful. Reinforcing Gulati's point that trained teachers are a key factor in providing 'education for all,' Robinson describes the work of the European Union-China Gansu Basic Education Project, which is using information and communication technologies to reach rural teachers on a large scale. Fully supported at all levels, the approach is system-wide rather than piecemeal, inclusive of all teachers in the target region, and based on technologies that are appropriate and relevant. So positive have the evaluations been to date that the project may well serve as the basis for much wider provision.

Siaciwena and Lubinda continue on this positive note in their case study of the role of open and distance learning in implementing the right to education in Zambia. Zambia is economically one of the poorest countries in the world, listed on the current Human Development Index as 13th from the bottom (UNDP, 2008). Focusing on the policy framework, the authors demonstrate the commitment of the Government of Zambia to further development of open and distance learning, and the progress that has so far been made. In order to continue this transformation of commitment into reality, there is an urgent need for training of personnel, capacity building in human and technological infrastructure, continuing evaluation and review, quality assurance frameworks, and establishment of partnerships with technology providers as well as a national consortium of materials producers and disseminators.

The final paper speaks more generally to the question of distance education's role in implementing the individual's right - and in this case, access - to education. The individual in question is the first generation student (FGS) in Canada, that is, the student whose parents did not attend university. Priebe, Ross and Low explore the issue of why distance education programs might have a higher proportion of FGS than do more conventional programs. Their research points up a number of possible answers, including the advanced age of these students in entering university which makes open, distance, and independent study an attractive option; and their determination to remain debt-free, which again makes distance and part-time study an appealing mix since it offers learners the possibility of remaining employed while studying. This paper makes a fitting close to the volume, by bringing us back to a consideration of the needs and characteristics of learners, which remain the foundation of our work of widening access to education and learning.

\section{Acknowledgements}

Any journal issue is only as good or as useful as the contributions of the authors who respond to the call for papers, and in this case we have, indeed, been well served by our contributors. Many thanks also to our peer reviewers for their guidance and advice. The issue would not have been possible without them, or without the steadfast intellectual, academic and editorial oversight and 
Barbara Spronk $\sim$ Editorial

Technology, Policy, and the Right to Education

Volume 9, Number 1, February 2008

organization provided by Paula Smith and Terry Anderson. I am most grateful to them for allowing me the opportunity to be part of this international initiative.

\section{References}

Bradley, J. (Ed.) (2003). The Open Classroom: Distance learning in and out of schools. London and Sterling, VA.: Kogan Page.

Perraton, H. (2000). Open and distance learning in the developing world. London and New York: Routledge.

Tait, A., \& Mills, R. (Eds.) (2003). Rethinking learner support in distance education: change and continuity in an international context. London and New York: RoutledgeFalmer.

UNDP (2008). Human development index statistics 2008. Retrieved February 19, 2008 from:A http://hdr.undp.org/en/statistics/

UNESCO (2008). Education for All - Global Monitoring Report 2008. Retrieved February 19, 2008 from:

http://portal.unesco.org/education/en/ev.php.url id=49591\&url_do=do topic\&url_sectio $\underline{\mathrm{n}=201 . \mathrm{html}}$

Yates, C., \& Bradley, J. (Eds.) (2000). Basic education at a distance. London and New York: RoutledgeFalmer and Vancouver: Commonwealth of Learning.

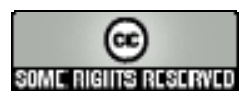

